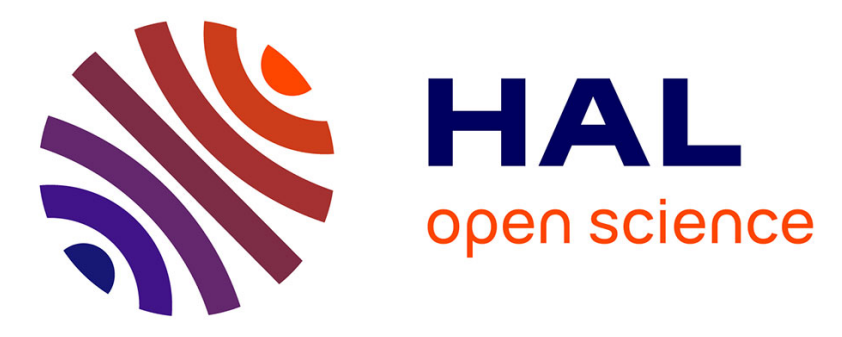

\title{
Electron Spin Resonance (ESR) Dating of Hominid-Bearing Deposits in the Caverna delle Fate, Ligure, Italy
}

Christophe Falguères, Yuji Yokoyama, Roland Bibron

\section{To cite this version:}

Christophe Falguères, Yuji Yokoyama, Roland Bibron. Electron Spin Resonance (ESR) Dating of Hominid-Bearing Deposits in the Caverna delle Fate, Ligure, Italy. Quaternary Research, 1990, 34, pp.121-128. halshs-00406246

\section{HAL Id: halshs-00406246 \\ https://shs.hal.science/halshs-00406246}

Submitted on 21 Jul 2009

HAL is a multi-disciplinary open access archive for the deposit and dissemination of scientific research documents, whether they are published or not. The documents may come from teaching and research institutions in France or abroad, or from public or private research centers.
L'archive ouverte pluridisciplinaire HAL, est destinée au dépôt et à la diffusion de documents scientifiques de niveau recherche, publiés ou non, émanant des établissements d'enseignement et de recherche français ou étrangers, des laboratoires publics ou privés. 


\title{
Electron Spin Resonance (ESR) Dating of Hominid-Bearing Deposits in the Caverna delle Fate, Ligure, Italy
}

\author{
Christophe Falgueres, ${ }^{*}$ Yuji Yokoyama, ${ }^{*}$ and Roland Bibron $\dagger$ \\ *Institut de Paléontologie Humaine, UR-184 du CNRS, I rue R. Panhard, 75013 Paris, France, and Centre \\ des Faibles Radioactivités, Laboratoire mixte CNRS-CEA, 91190, Gif sur Yvette. France \\ Received January 24, 1989
}

\begin{abstract}
Stalagmitic floors interstratified with Mousterian deposits from the Caverna delle Fate (Italy) have been dated by the electron spin resonance (ESR) method. Three samples dated fall between 60,000 and $74,000 \mathrm{yr}$ and indicate the age of the Mousterian deposits. They are in good agreement with ages determined by nondestructive $\gamma$-ray spectrometry of the human remains from ${ }^{231} \mathrm{~Pa}^{235} \mathrm{U}$ and ${ }^{230} \mathrm{Th} / 234 \mathrm{U}$ ratios, which are, respectively, 75,000 ${ }_{-14,000}^{+21.000}$ and $82,000{ }_{-25,000}^{+36.000} \mathrm{yr}$. These dates are consistent with the morphological characteristics of the bones as Neanderthal remains. 1990 University of Washington.
\end{abstract}

\section{INTRODUCTION}

The Caverna delle Fate (Cave of the Fairies) is located $5 \mathrm{~km}$ northeast of Finale (Ligure, Italy) (Fig. 1). A wide opening toward the southwest reveals a large hall that extends southward, via a corridor, to a series of galleries and halls extending $150 \mathrm{~m}$.

A large quantity of animal bones and lithic materials were discovered in the Mousterian layers during excavations at the end of the 19th century (Amerano, 1889). Human fossil remains were identified by G. Giacobini (Giacobini and de Lumley, 1983) during a recent revision of the bone assemblage collected by Amerano. The human remains are represented by an incomplete frontal bone of a child (Fate I), an almost complete mandible of a child (Fate II), and a fragment of an adult right half-mandible (Fate III) (Giacobini et al., 1984). Examination of these remains disclosed several Neanderthal features, in keeping with the finding of a Mousterian industry in these layers. However, the remains display some modern features. At present, it is difficult to specify whether the features which are not classical Neanderthalian characteristics have evolutionary significance or are due to regional variations.

The human remains have been dated by nondestructive $\gamma$-ray spectrometry using a high-purity germanium $\gamma$-x detector (Giacobini et al., 1984). Activity of radionuclides in the human bones is given in Table 1. The ages deduced from the ${ }^{231} \mathrm{~Pa} /{ }^{235} \mathrm{U}$ and ${ }^{230} \mathrm{Th} /$ ${ }^{234} \mathrm{U}$ ratios are, respectively, $75,000_{-14,000}^{+21,000}$ and $82,000+25,000 \mathrm{yr}$.

Discovery of the human remains and their dating has so revived interest in this exceptional site that new excavations were carried out between 1984 and 1988 by a Franco-Italian team under the direction of G. Giacobini, G. Vicino, and H. de Lumley. Their purpose was to establish the chronostratigraphy of the deposits in relation to the human remains. This new excavation led to the discovery of further remains, including a fragment of parietal bone which can be anatomically connected with the previously discovered child's frontal bone (Fate I). Unfortunately, these new human remains were discovered in the waste of the old excavations so that their stratigraphic position has not been established. The new excavation, however, revealed that the Mousterian deposits are interstratified with several stalagmitic floors. Therefore, the radiometric dating of these floors is useful in establishing closer relationships between the human remains and the chronostratigraphy of the deposits. For this pur- 

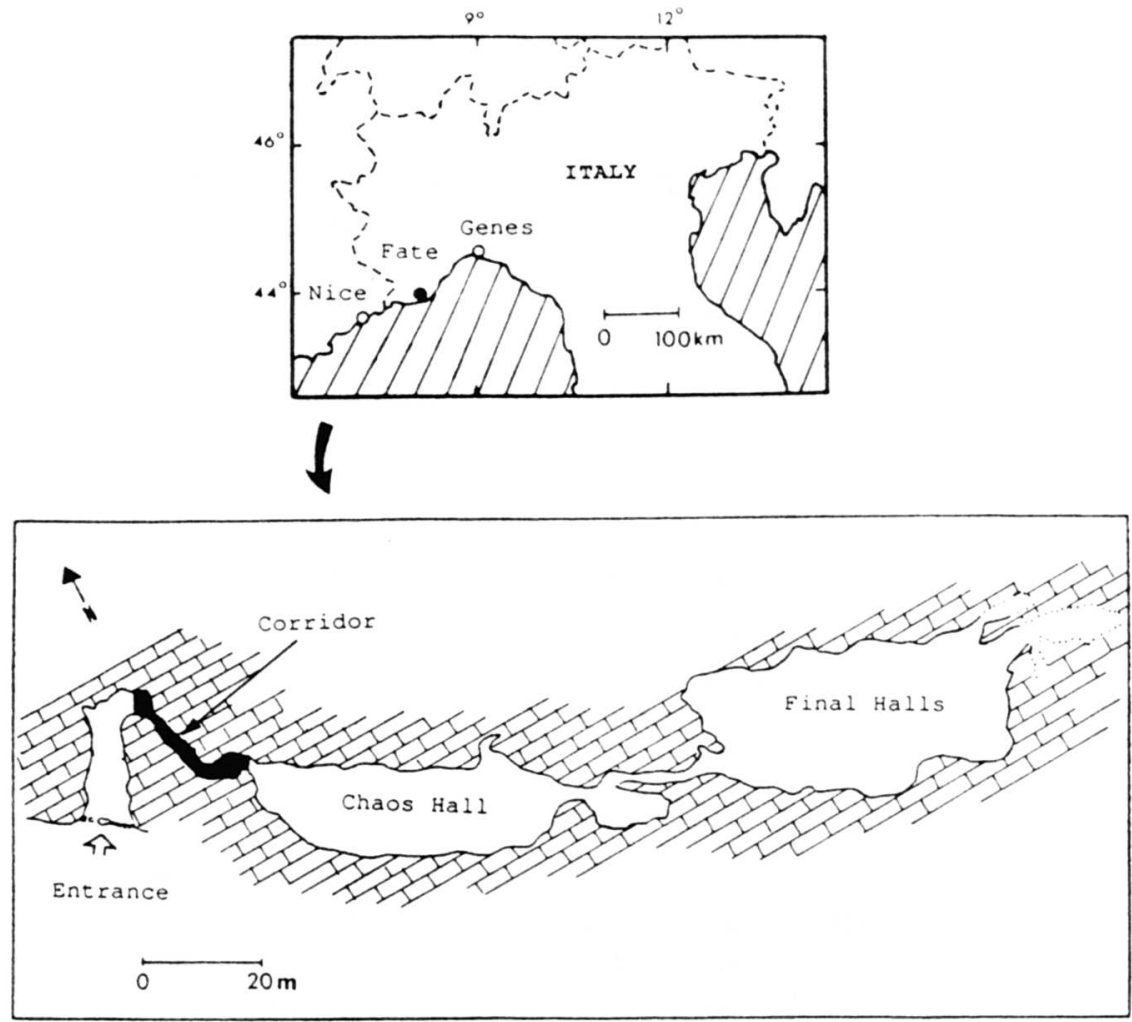

FIG. 1. Map of the Caverna delle Fate in a karst region of northwestern Italy. The dark zone represents Amerano's excavation corridor where the studied samples were extracted. This corridor is followed by a large hall, called Chaos Hall, and other complex galleries and rooms.

pose, we have dated three calcite samples by the electron spin resonance method (ESR).

\section{SAMPLES}

Amerano's excavations in the corridor (dark part) of the cave (Fig. 1) permitted the identification of archaeological layers from

TABLE 1. Activity of Radionuclides in the THReE Human Bones

\begin{tabular}{cc}
\hline Nuclide & Activity $(\mathrm{dpm} / \mathrm{g})$ \\
\hline${ }^{238} \mathrm{U}$ & $2.70 \pm 0.04$ \\
${ }^{234} \mathrm{U}$ & $3.21 \pm 0.60$ \\
${ }^{230} \mathrm{Th}$ & $1.74 \pm 0.19$ \\
${ }^{226} \mathrm{Ra}$ & $1.35 \pm 0.09$ \\
${ }^{222} \mathrm{Rn}$ & $0.78 \pm 0.01$ \\
${ }^{210} \mathrm{~Pb}$ & $0.78 \pm 0.10$ \\
${ }^{231} \mathrm{~Pa}$ & $0.099 \pm 0.008$ \\
${ }^{228} \mathrm{Ra}$ & $0.06 \pm 0.02$ \\
${ }^{228} \mathrm{Th}$ & $0.06 \pm 0.01$
\end{tabular}

Mousterian to Middle Neolithic. The artifacts collected in the old layers have been classified as a typical Mousterian assemblage, rich in scrapers, with Levallois technique and of non-Levalloisian facies (de Lumley, 1969). The exact position of the human remains in the cave is not known, but we assume that they were collected in this corridor together with the other materials.

The samples used for the present study are speleothems collected from this part of the cave. They belong to two stalagmitic floors which are interstratified in the Mousterian layers (Fig. 2). Three samples (F85-2, F-85-9, and F-85-10) were studied.

\section{ESR DATING OF CALCITE SAMPLES}

\section{Method}

ESR signal intensity is proportional to 


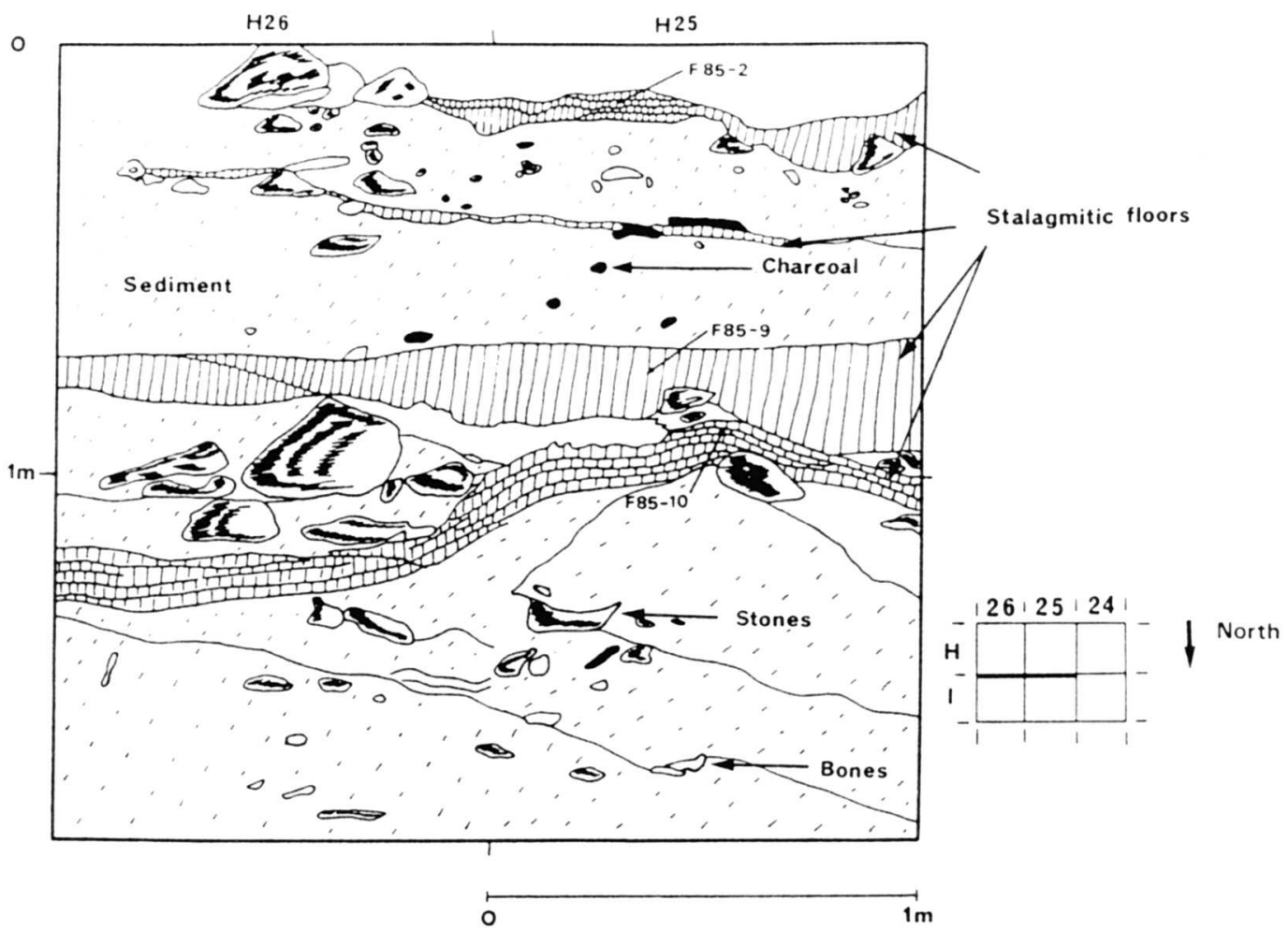

FIG. 2. Stratigraphic position of the three studied samples. This vertical section shows the Mousterian deposits interstratified with stalagmitic floors in the corridor. This section was made against the south wall of the corridor. Sediments are silty clay loam with gravels (about $15 \%$ ).

the number of trapped electrons accumulated from the moment of calcite formation until the present. These trapped electrons are due to the action of the ionizing radiations $(\alpha, \beta, \gamma)$. Measurement of their number permits the dating. The ESR age of a sample is determined by the relation

$$
\mathrm{ED}=\int_{0}^{t} \mathrm{AD} d t
$$

where ED is the equivalent radiation dose received by the sample during its entire age, $\mathrm{AD}$ is the annual radiation dose, and $t$ is the age. The annual dose is a sum of the doses due to different radiations,

$$
\mathrm{AD}=k \cdot \mathrm{D} \alpha+\mathrm{D} \beta+\mathrm{D} \gamma+\mathrm{Dcosmic},
$$

where $\mathrm{D} \alpha, \mathrm{D} \beta$, and $\mathrm{D} \gamma$ are the annual doses due to $\alpha$-rays, $\beta$-rays, and $\gamma$-rays, respectively. Dcosmic is the annual dose due to cosmic rays, and $k$ is the sensitivity ratio between the $\alpha$-rays and the other radiations ( $k$ value).

The $\mathrm{D} \alpha$ and $\mathrm{D} \beta$ are due to the radioactive elements, principally uranium and its daughters, included in the calcite. Since the newly formed calcite contains only uranium without its daughters, the $D \alpha$ and $D \beta$ increase with time according to the formation of the uranium descendants ${ }^{230} \mathrm{Th}$ and ${ }^{231} \mathrm{~Pa}$ and their daughters. The D $\gamma$ is essentially due to $\gamma$-rays coming from the sediment. These annual doses are determined from the uranium, thorium, and potassium contents of the calcite and the sediment (Yokoyama et al., 1982).

ESR spectra of natural palaeolithic calcites usually show three radiation-induced lines termed by Yokoyama et al. (1983) h1 


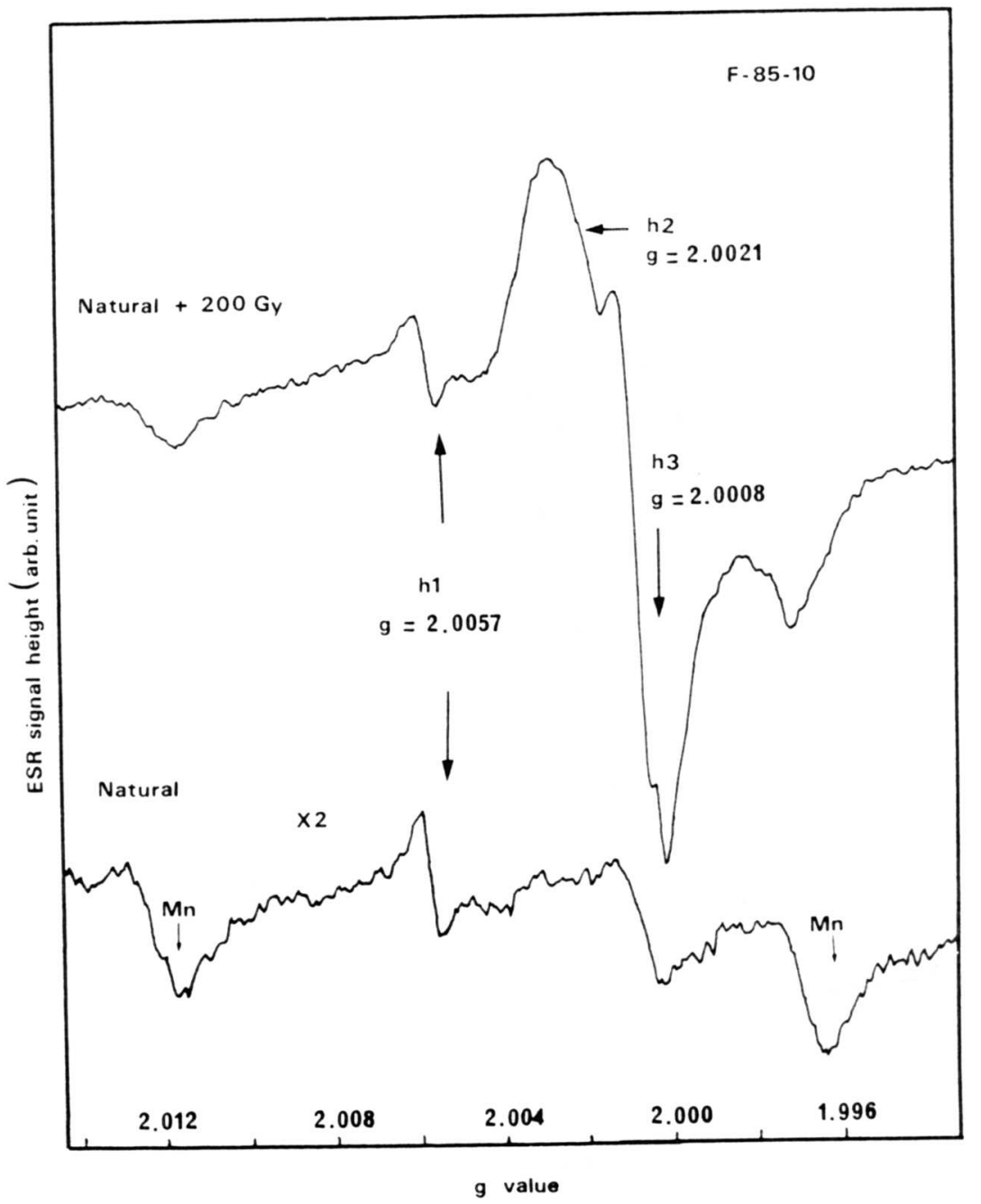

FIG. 3. ESR spectra of natural and irradiated calcite sample (F-85-10) of the Caverna delle Fate. A scanning speed of $8 \mathrm{~min}$ is used for these spectra.

( $g=2.0057), \mathrm{h} 2(g=2.0021)$, and h3 ( $g=$ 2.0008) (Fig. 3). Another radiation-induced line, called Broad-Line (BL) at $g=2.004$, has been pointed out by Apers et al. (1981). These signals are due to trapped electrons and can be used for dating, except h2 which is not sufficiently stable.

Measurements were made at room temperature using a Varian E109 X-band spectrometer. The experimental conditions

TABle 2. Experimental Conditions for Observation of Calcite Signals in this Study

\begin{tabular}{cccccc}
\hline ESR signals & $g$ value & $\begin{array}{c}\text { Microwave } \\
\text { power }(\mathrm{mW})\end{array}$ & Modulation $(G)$ & Scan range $(G)$ & $\begin{array}{c}\text { Cavity } \\
\text { temperature }\left({ }^{\circ} \mathrm{K}\right)\end{array}$ \\
\hline h1 & 2.0057 & 5 & 0.5 & 80 & 293 \\
h3 & 2.0008 & 5 & 0.5 & 80 & 293 \\
BL & 2.0040 & 0.1 & 5 & 80 & 293 \\
\hline
\end{tabular}




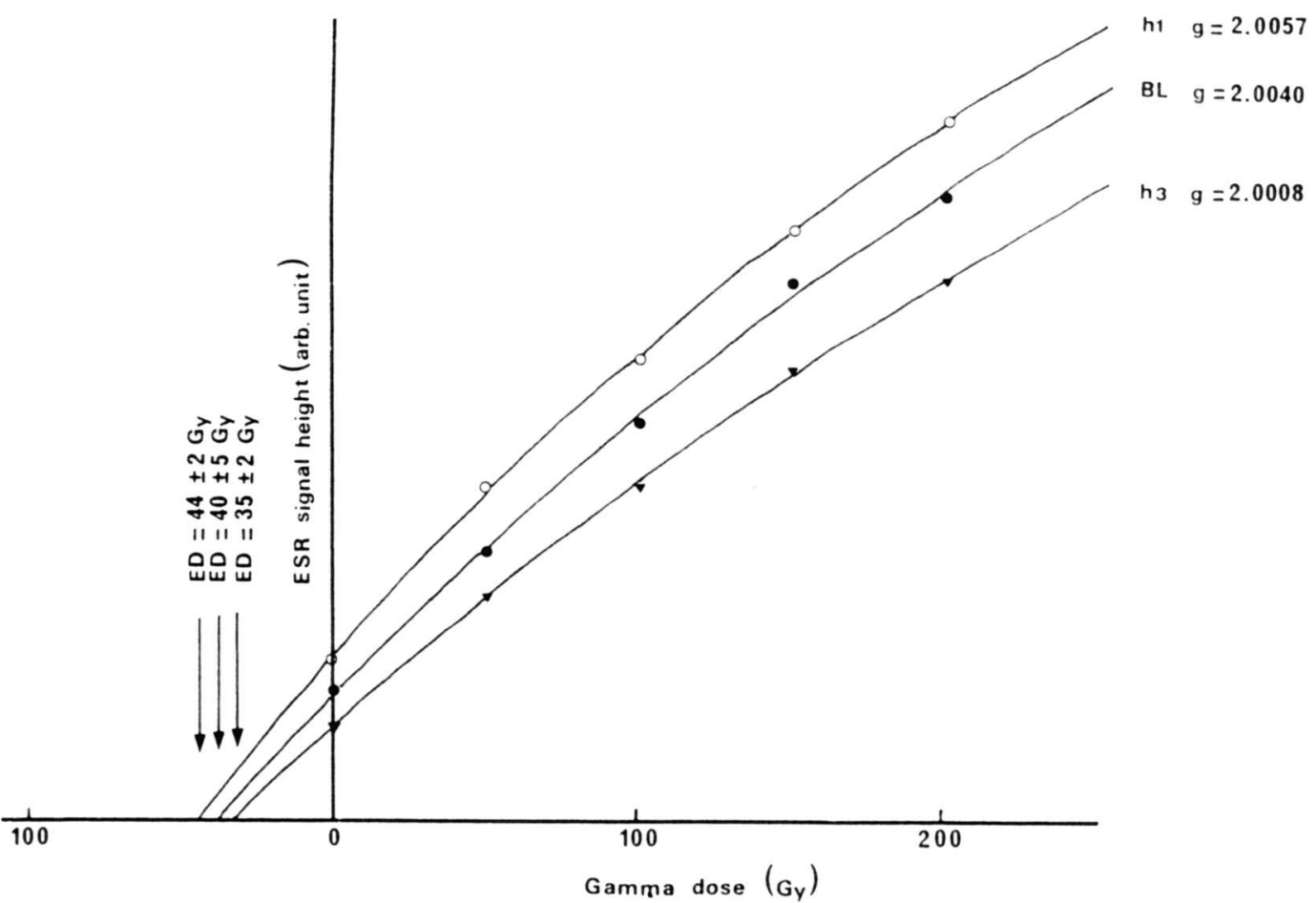

FIG. 4. Determination of the equivalent doses for the three ESR signals, h1, h3, and BL, by the additive method for F-85-10 sample.

were the same for the measurement of $\mathrm{hl}$ and h3 signals (Table 2). The Broad-Line signal was observed with a weaker microwave power of $0.1 \mathrm{~mW}$ and a wider modulation amplitude of 5 Gauss because it saturates at a low microwave power and because it is a wider signal than the others (Yokoyama et al., 1985). The measurement of h1 signal was carried out after thermal pretreatment at $180^{\circ} \mathrm{C}$ for $16 \mathrm{hr}$ (Yokoyama et al., 1983).

Results

The equivalent doses (ED) of the three samples are determined by the additive method (Fig. 4). For each sample, the ED is determined for $h 1, h 3$, and BL signals. The results are in good agreement with respect to the $\sigma$ errors.

Uranium content is low in these stalagmite samples. The internal annual dose is determined as a function of time because of the growth of the ${ }^{230} \mathrm{Th}$ (and ${ }^{231} \mathrm{~Pa}$ ) from their parents. For the age calculation, this variation has been taken into account. For the annual doses, the errors are estimated as $10 \%$. In Table 3 , the internal annual doses are given for the time of precipitation (deposition) $(t=0)$ and for the present $(t$ $=t$ ).

The external doses were determined by $\gamma$-ray spectrometry of the surrounding sediments. A water content of $15 \%$ in the sediment was used for calculation of the external dose. $\gamma$-rays coming from the sediments are attenuated in the stalagmitic floors. The attenuation factor is calculated with the equation

$$
\begin{aligned}
A= & 0.5[\exp (-m * D) \\
& +m * D * \operatorname{Ei}(-m * D)]
\end{aligned}
$$

where $A$ is the fraction of the $\gamma$-rays 
reached at the distance $D\left(\mathrm{~g} / \mathrm{cm}^{2}\right)$ from the sediment, $m$ is the attenuation coefficient of the $\gamma$-ray $\left(\mathrm{cm}^{2} / \mathrm{g}\right)$, Ei is the exponential integration function, and 0.5 is the $2 \pi$ geometric factor (Yokoyama et al., 1987). The mean attenuation coefficient of $\gamma$-rays from the uranium series is $0.070 \mathrm{~cm}^{2} / \mathrm{g}$, that of the thorium series is $0.067 \mathrm{~cm}^{2} / \mathrm{g}$, and that of potassium $0.054 \mathrm{~cm}^{2} / \mathrm{g}$ (Yokoyama et al., 1982). We adopted a mean value of 0.065 $\mathrm{cm}^{2} / \mathrm{g}$. If a stalagmitic floor is sandwiched between two sediment layers, $\gamma$-rays coming from these two layers should be added.

For the three calcite samples from the Fate cave, the attenuation factors are estimated as $0.90,0.60$, and 0.50 for F-85-2, F-85-9, and F-85-10 samples, respectively. The cosmic dose is estimated as $50 \mathrm{mGy} / \mathrm{yr}$. A $k$ value (sensibility ratio between $\alpha$-ray and $\beta$-ray) of 0.265 and a ${ }^{234} \mathrm{U} /{ }^{238} \mathrm{U}$ ratio equivalent to $1.2 \pm 0.1$ have been taken into account for the annual dose calculation. The resulting ages are $60,000 \pm 7000$, $72,000 \pm 8000$, and $74,000 \pm 10,000 \mathrm{yr}$, respectively, for samples F-85-2, F-85-9, and F-85-10 (Table 3).

According to Bichet (1987) the sediment between the two studied stalagmitic floors corresponds to a cold period. Speleothems usually grow during hu aid and temperate climate conditions.

Taking into account $1 \mathrm{\sigma}$ error, the ages suggest that the stalagmitic floor from which samples F-85-9 and F-85-10 were collected likely dates to isotope substage $5 \mathrm{a}$ and (or) the early part of stage 4 . In consideration of the two points previously mentioned, we think that this carbonate formation most likely grew during the last part of isotope stage 5 (Fig. 5).

The speleothem that contains F-85-2 grew in stage 4 and (or) the beginning of isotope stage 3. For the same reasons, we think that this carbonate deposit probably dates to the beginning of isotope stage 3 .

The ages of the human remains previously determined by nondestructive $\gamma$-ray spectrometry are compatible with the new ESR ages of the deposits. This agreement gives additional support to the assumption that the human remains were collected in Amerano's excavated corridor and probably came from deposits dating between oxygen isotopic stage 3 and substage 5 a.

\section{ACKNOWLEDGMENTS}

We thank H. de Lumley and G. Giacobini for samples and discussion. We are grateful to C. Chachaty of

table 3. Equivalent Doses, annual Doses, and Ages of the Fate Samples

\begin{tabular}{|c|c|c|c|c|c|c|c|c|}
\hline \multirow[b]{3}{*}{ Sample } & \multirow[b]{3}{*}{$\mathrm{U}(\mathrm{ppm})$} & \multirow{3}{*}{$\begin{array}{l}\text { Equivalent } \\
\text { dose (Gy) }\end{array}$} & \multicolumn{4}{|c|}{ Annual dose (mGy/yr) } & \multirow{3}{*}{\multicolumn{2}{|c|}{ Age $\left(10^{3} \mathrm{yr}\right)$}} \\
\hline & & & \multicolumn{2}{|c|}{ Internal } & \multicolumn{2}{|c|}{ External } & & \\
\hline & & & $t=0$ & $t=t$ & Gamma & Cosmic & & \\
\hline F-85-2 & 0.180 & $\begin{array}{ll}\text { h3 } & 57 \pm 5 \\
\text { h1 } & 51 \pm 1 \\
\text { BL } & 53 \pm 4\end{array}$ & 47 & 123 & 744 & 50 & $\left.\begin{array}{l}64 \pm 9^{a} \\
58 \pm 6 \\
60 \pm 8\end{array}\right\}$ & $60 \pm 7^{b}$ \\
\hline F-85-9 & 0.166 & $\begin{array}{ll}\text { h3 } & 44 \pm 1 \\
\text { h1 } & 50 \pm 4 \\
\text { BL } & 46 \pm 2\end{array}$ & 43 & 122 & 496 & 50 & $\left.\begin{array}{rl}69 & \pm 8 \\
77 & \pm 10 \\
72 & \pm 8\end{array}\right\}$ & $72 \pm 8$ \\
\hline F-85-10 & 0.129 & $\begin{array}{ll}\text { h3 } & 35 \pm 2 \\
\text { h1 } & 44 \pm 2 \\
\text { BL } & 40 \pm 3\end{array}$ & 34 & 97 & 414 & 50 & $\left.\begin{array}{l}66 \pm 8 \\
82 \pm 9 \\
75 \pm 9\end{array}\right\}$ & $74 \pm 10$ \\
\hline
\end{tabular}

${ }^{a}$ The errors are quadratical addition of the equivalent dose errors and the annual dose errors. For the equivalent dose errors, a minimum of $5 \%$ is used if the observed errors are smaller than this value.

${ }^{b}$ The average ages are calculated from the weighted average of equivalent doses of the three signals hl, h3. and $\mathrm{BL}$. 

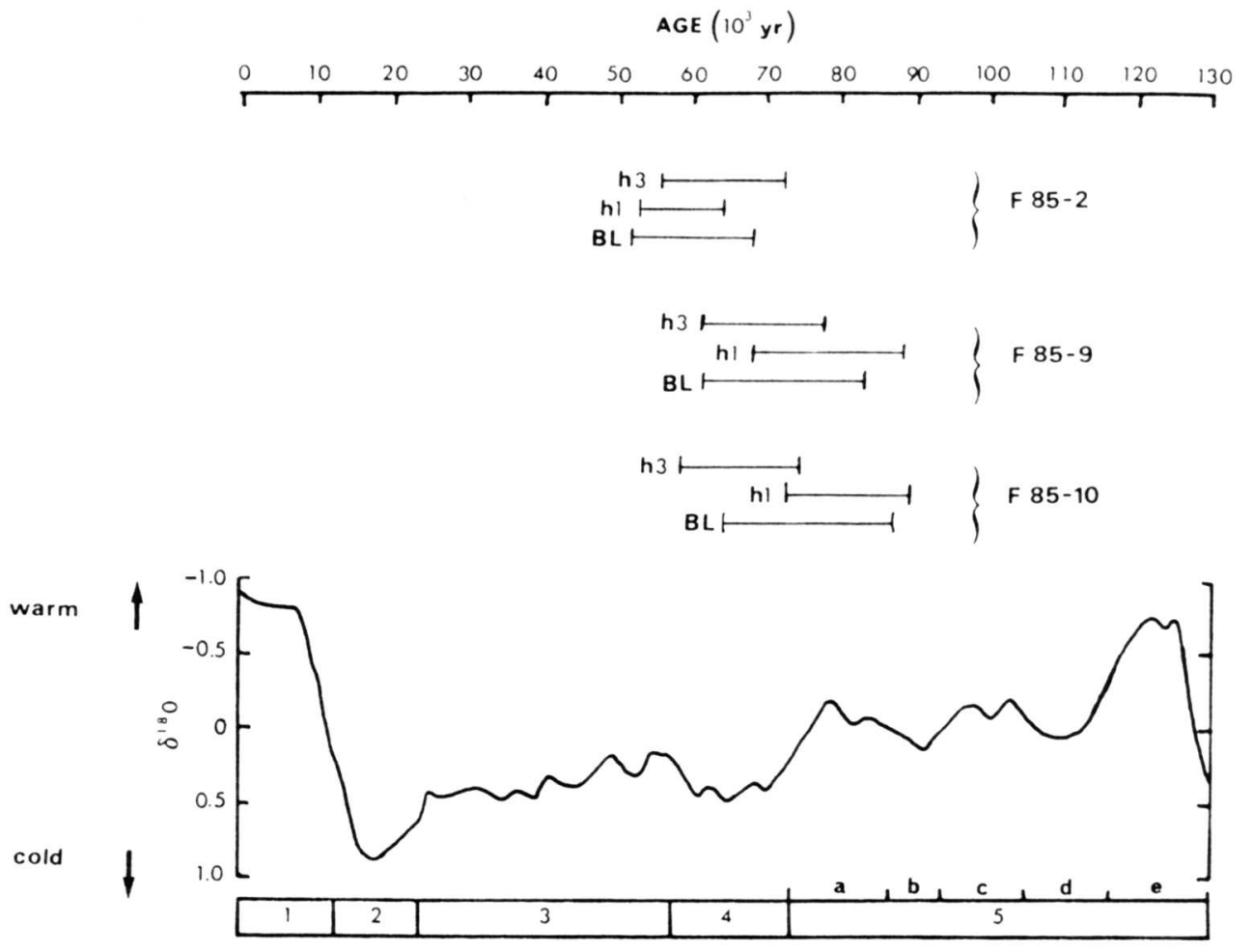

Marine Isotope Stages

FIG. 5. The time span of growth of the studied stalagmitic floors of the Caverna delle Fate with respect to the variation of $\delta^{18} \mathrm{O}$ of themarine isotope stages (Martinson et al., 1987). For each sample, three induced signals (h1, h3, and $\mathrm{BL}$ ) have been used to determine the age.

the Département de Physico-chimie du Centre Nucléaire de Saclay and to B. Morin of the Département de Spectrochimie de Paris VI for the use of ESR spectrometer. We thank J. J. Bahain of the Centre des Faibles radioactivités de Gif sur Yvette for his help in the experiment.

\section{REFERENCES}

Amerano, G. B. (1889). La caverna delle Fate (Ligurie). In "Congrès international d'Anthropologie et d'Archéologie préhistorique." Compte rendu de la dixième session à Paris, pp. 173-182. Paris.

Apers, D., Debuyst, R., Decanniere, P., Dejehet, F., and Lombard, E. (1981). A criticism of the dating by electronic paramagnetic resonance (ESR) of the stalagmitic floors of the Caune de l'Arago at Tautavel. In "Absolute Dating and Isotope Analysis in Prehistory: Methods and Limits" ( $\mathrm{H}$. de Lumley and J. Labeyrie, Eds.), pp. 533-550.

Bichet, V. (1987). "Contribution à l'étude sédimentologique du remplissage karstique de la caverna delle Fate (Ligurie italienne). Essai chronostratigraphique." D.E.A. Museum National d'Histoire Naturelle, Paris.

Giacobini, G., and Lumley de, M. A. (1983). Restes humains néandertaliens de la caverna delle Fate (Finale, Ligurie italienne). Anthropologie 87, 142-144.

Giacobini, G., Lumley de, M. A., Yokoyama, Y., and Nguyen, H. V. (1984). Neanderthal child and adult remains from a mousterian deposit in northern Italy (Caverna delle Fate, Finale, Ligure). Journal of $\mathrm{Hu}$ man Evolution 13, 687-707.

Lumley de, H. (1969). Le Paléolithique inférieur et moyen du midi méditerranéen dans son cadre géologique. (CNRS, Ed.), Paris, $5^{\mathrm{e}}$ supplément Gallia Préhistoire.

Martinson, D. G., Pisioas, N. G., Hays, J. D., Imbrie, J., Moore, T. C., Jr., and Shackleton, N. J. (1987). Age dating and the orbital theory of the ice ages: Development of a high-resolution 0 to 300,000 year chronostratigraphy. Quaternary Research 27, 1-29.

Yokoyama, Y., Nguyen, H. V., Quaegebeur, J. P., and Poupeau, G. (1982). Some problems encoun- 
tered in the evaluation of annual dose-rate in the electron spin resonance dating of fossil bones. PACT 6, 103-115.

Yokoyama, Y., Quaegebeur, J. P., Bibron, R., and Léger, C. (1983). ESR Dating of Palaeolithic calcite: Thermal annealing experiment and trapped electron lifetime. PACT 9, 371-379.

Yokoyama, Y.. Bibron, R., Léger, C., and Quaege- beur, J. P. (1985). ESR dating of Palaeolithic calcite: Fundamental studies. Nuclear Tracks 10(4-6), 921928.

Yokoyama. Y., Bahain, J. J., Tucholka, P., and Bibron, R. (1987). Stability of trapped electrons in ESR dating of Quaternary calcite: Comparison with palaeomagnetism $5^{\text {th }}$ Specialist Seminar TL and ESR Dating, Cambridge, July 6-10. 